\title{
Sandflies in an endemic area for Visceral Leishmaniasis in Northeastern Brazil
}

\author{
Flebotomíneos em uma área endêmica para Leishmaniose Visceral no Nordeste do Brasil \\ Jonatas Abinadabe Oliveira Silva ${ }^{1,2}$; Fernando José da Silva ${ }^{3}$; Lucia Oliveira de Macedo ${ }^{4}$; \\ Cléber Vinícius Brito dos Santos ${ }^{5}$; Leucio Câmara Alves ${ }^{6}$; Rafael Antonio Nascimento Ramos ${ }^{4}$; \\ Maria Aparecida da Gloria Faustino ${ }^{6}$; Gílcia Aparecida de Carvalho ${ }^{4 *}$ (D) \\ ${ }^{1}$ Programa de Ciência Animal Tropical, Universidade Federal Rural de Pernambuco - UFRPE, Recife, PE, Brasil \\ ${ }^{2}$ Departamento de Vigilância Sanitária, Secretaria Municipal de Saúde de Goiana, Goiana, PE, Brasil \\ ${ }^{3}$ Centro de Pesquisas Aggeu Magalhães, Fundação Oswaldo Cruz - FIOCRUZ, Recife, PE, Brasil \\ ${ }^{4}$ Unidade Acadêmica de Garanhuns, Universidade Federal Rural de Pernambuco - UFRPE, Garanhuns, PE, Brasil \\ ${ }^{5}$ Instituto de Medicina Social, Universidade do Estado do Rio de Janeiro - UERJ, Rio de Janeiro, RJ, Brasil \\ ${ }^{6}$ Departamento de Medicina Veterinária, Universidade Federal Rural de Pernambuco - UFRPE, Recife, PE, Brasil
}

Received April 23, 2019

Accepted August 22, 2019

\begin{abstract}
Phlebotomines of the genus Lutzomyia are important vector for species of Leishmania, the etiological agent of leishmaniasis. The aim of this study was to assess the diversity of sandflies in an endemic area for Visceral Leishmaniasis (VL). Sampling was performed in four localities on the coast of the municipality of Goiana, state of Pernambuco, Northeastern Brazil. Specimens were collected monthly on three consecutive nights, from November 2017 to October 2018. CDC light traps were installed at a height of $1.5 \mathrm{~m}$ above the ground, in two ecotypes (i.e. tree and animal facility), both in peridomestic areas. A total of 5,205 sandflies were collected, among which the species Lutzomyia longipalpis $(99.85 \% ; 5,197 / 5,205)$ was the most common, followed by Lutzomyia evandroi $(0.13 \%$; 07/5,205) and Lutzomyia whitmani $(0.02 \% ; 01 / 5,205)$. Specimens of L. longipalpis were collected throughout the study period and most of them were found near to the animal facilities. The findings from this research indicate that vectors for Leishmania infantum are present in the study area throughout the year, along with occurrences of vectors relating to Cutaneous Leishmaniasis (CL). Preventive vector control measures need to be implemented in Goiana to reduce the risk of infection for the human and animal populations.
\end{abstract}

Keywords: Phlebotomines, Leishmania infantum, Leishmania braziliensis, Lutzomyia longipalpis.

\section{Resumo}

Flebotomíneos do gênero Lutzomyia são importantes vetores de espécies de Leishmania, agente etiológico das leishmanioses. O objetivo deste estudo foi avaliar a diversidade de flebotomíneos em área endêmica para Leishmaniose Visceral (LV). As coletas foram realizadas em quatro localidades do litoral do município de Goiana, Pernambuco, Nordeste do Brasil. Os espécimes foram coletados mensalmente em três noites consecutivas de novembro de 2017 a outubro de 2018. Foram instaladas armadilhas luminosas modelo CDC a uma altura de $1,5 \mathrm{~m}$ acima do solo em dois ecótopos (ex. árvore e instalaçôes de animais), ambos em áreas peridomiciliares. Um total de 5.205 flebotomíneos foi coletado, sendo Lutzomyia longipalpis (99,85\%; 5.197/5.205) a mais comum, seguida por Lutzomyia evandroi (0,13\%; 07/5.205) e Lutzomyia whitmani $(0,02 \% ; 01 / 5.205)$. L. longipalpis foi coletada durante todo o período do estudo. A maioria dos espécimes foi detectada perto das instalaçóes dos animais. Os achados deste estudo indicam a presença de vetores de Leishmania infantum na área avaliada ao longo do ano, bem como a ocorrência de vetores relacionados à Leishmaniose Cutânea (LC). Medidas preventivas de controle vetorial devem ser implementadas em Goiana para reduzir o risco de infecção à população humana e animal.

Palavras-chave: Flebotomíneos, Leishmania infantum, Leishmania braziliensis, Lutzomyia longipalpis.

*Corresponding author: Gílcia Aparecida de Carvalho. Unidade Acadêmica 


\section{Introduction}

Sandflies (Diptera: Psychodidae) are insects of medical and veterinary concern because of their ability to transmit a plethora of pathogens (e.g. virus, bacteria and protozoa) to vertebrate hosts, including humans (MAROLI et al., 2013). These insects are widely distributed around the world and commonly use mammals and birds as sources of blood meals (COSTA et al., 2013; RIGG et al., 2019). Among the pathogens transmitted to mammals by sandflies, protozoa of the genus Leishmania (Kinetoplastida: Trypanosomatidae) have been considered to be the most epidemiologically important agents (MAROLI et al., 2013; AKHOUNDI et al., 2016).

Several species of Leishmania have been recognized. Among these, Leishmania (Viannia) braziliensis and Leishmania (Leishmania) infantum are the causative agents of Cutaneous Leishmaniasis (CL) and Visceral Leishmaniasis (VL), respectively (BRITO et al., 2012; LIMA et al., 2013). Both of these diseases (i.e. CL and VL) are endemic in several Brazilian states, including those in the northeastern region (SOUSA et al., 2018). In fact, this region is responsible for $44.5 \%$ of cases of VL in the country (BRASIL, 2018). In particular, between 2007 and 2017, 41,263 cases of VL and 235,301 of CL were diagnosed through the Brazilian national health system, and many of these were reported in the state of Pernambuco (SINAN, 2019).

Over the last few years, great efforts have been made through the Brazilian national health system to control the spreading of leishmaniasis. Nonetheless, in some areas, the numbers of cases have increased, and outbreaks have been described in regions where the disease had been considered absent (SALES et al., 2019). This spreading has been related to degradation of natural habitats that may force sandflies to adapt to the modified environment (ANTONINI et al., 2017). This increases the risk of Leishmania transmission in peridomestic and domestic environments. The vector role of a sandfly population depends not only on vector competence (i.e. the ability to facilitate development of infective forms of Leishmania), but also on vector capacity, which depends partly on ecological associations (READY, 2013).

Some entomological surveys have been conducted in northeastern Brazil (GUIMARÁES et al., 2012; COSTA et al., 2013; MIRANDA et al., 2015; AGRA et al., 2016), but mostly in the interior of this region, while the coast has been less explored (LUCENA et al., 1984; SILVA et al., 2017a). In northeastern Brazil, Lutzomyia whitmani has generally been one of the more common species incriminated as a vector for L. braziliensis, whereas L. longipalpis is considered to be the most important transmitter of L. infantum (ANDRADE-FILHO et al., 2017; SILVA et al., 2017b; PESSOA-E-SILVA et al., 2019). It is known that many cases of CL and VL occur in areas where fragments of Atlantic Forest are present.

Therefore, the aim of the present study was to assess the diversity of sandflies in a known endemic area for VL.

\section{Materials and Methods}

\section{Study area}

This study was conducted in the municipality of Goiana (07033'38" south and 3500'09" west), in the state of Pernambuco, northeastern Brazil. Sampling was performed in four localities on the coast known as Carne de Vaca, Atapuz, Ponta de Pedras and Barra de Catuama. This area is characterized by the presence of fragments of Atlantic Forest and mangroves. The climate is tropical-humid, with a rainy season from March to July. The mean annual temperature is around $24.9^{\circ} \mathrm{C}$ and the mean annual rainfall is $1,924 \mathrm{~mm}$ (GOIANA, 2019). Climatic information was obtained from the Pernambuco Water and Climate Agency (Agência Pernambucana de Águas e Clima, APAC).

Currently, the municipality of Goiana is considered to be a priority location for healthcare services regarding actions against neglected diseases, including leishmaniasis. From 2007 to 2017, 14 autochthonous cases of VL were reported (SINAN, 2019), along with cases of canine leishmaniasis (PESSOA-E-SILVA et al., 2019).

\section{Sampling and identification of sandflies}

Specimens were collected monthly on three consecutive nights between November 2017 and October 2018. CDC light traps $(\mathrm{n}=16)$ were installed at $5 \mathrm{pm}$ and remained in place until $5 \mathrm{am}$. Each trap was placed at a height of $1.5 \mathrm{~m}$ above the ground, in two ecotypes, a tree and animal facility, both in peridomestic areas. In particular, traps were installed as follows: Carne de Vaca (P1 and P2 - tree; P3 and P4 - animal facility); Atapuz (P5 and P6 - tree; P7 and P8 - animal facility); Ponta de Pedras (P9 - tree; P10 to P12 - animal facility); and Barra de Catuama (P14 and P15 - tree; P13 and P16 - animal facility). All traps were georeferenced through the satellite remote sensing Global Positioning System (GPS) Garmin Etrex20 (Figure 1).

All the specimens collected were morphologically identified in accordance with the dichotomous key of Young \& Duncan (1994).

\section{Data and spatial analyses}

The results were analyzed by means of descriptive statistics. In addition, the Lilliefors test was used to verify the normality of the data. The relationships between the number of sandflies and the climatic variations were evaluated by cross-correlation coefficient.
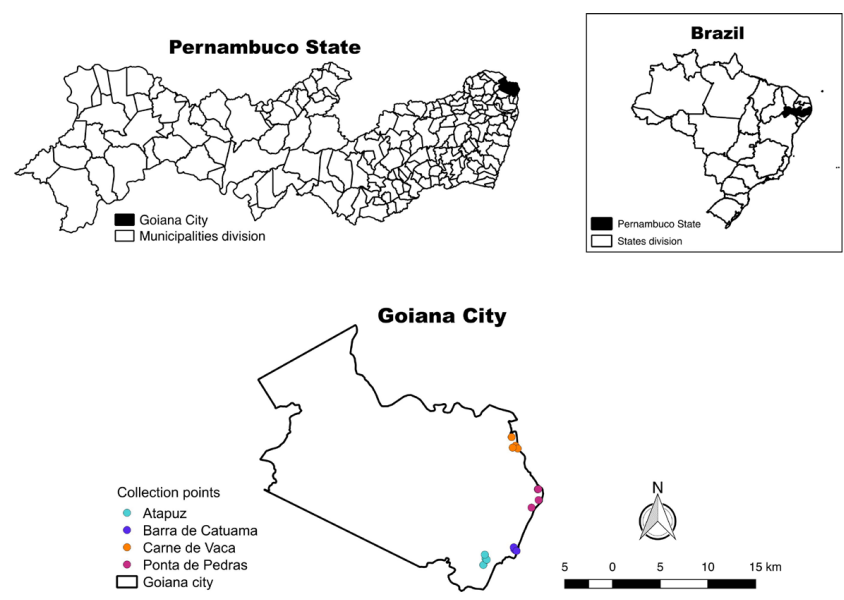

Figure 1. Spatial distribution of collection points on the coast of Goiana, Pernambuco, Brazil. 
The proportions of males and females, as well as localities and collection points, were compared using $95 \%$ confidence intervals constructed from the binomial distribution. The chi-square $\left(x^{2}\right)$ test with Yates correction was used to compare occurrences of phlebotomine species in both ecotypes. The significance level was taken to be $5 \%$. The $\mathrm{R}$ software version 3.4.3 and BioEstat version 5.3 were used to perform the statistical analyses.

The plane coordinates obtained by GPS were used for each collection point. The georeferenced data were entered into the QGIS version 2.8 and spatial distribution of the sandflies was evaluated using kernel density estimation (KDE). KDE is a non-parametric method that generates a continuous density surface from point data. It is a smoothing and interpolating technique for generalizing point location for the whole study area. In addition it is a simple alternative to analyze focal patterns, in which the outputs are easily readable and understood (REGIS et al., 2013). The results were plotted using QGIS software.

\section{Results}

A total of 5,205 sandflies were caught, males predominated $(51.76 \% ; 2,694 / 5,205)$ over females $(48.24 \% ; 2,511 / 5,205)$ $(\mathrm{p}<0.05)$, being the sex ratio (M:F) of 1.07:1. Three species of phlebotomines were identified: L. longipalpis $(99.85 \% ; 5,197 / 5,205)$ was the most frequent species, followed by Lutzomyia evandroi $(0.13 \% ; 7 / 5,205)$ and L. whitmani $(0.02 \% ; 1 / 5,205)$. Sandflies were retrieved from 13 collection points, and L. longipalpis was detected at all positive points, with highest frequency in Atapuz $(97.92 \% ; 5,089 / 5,197)$ and with predominance in the point P8 $(\bar{x}=355.00 \pm 129.62)$ (Table 1$)$. The collection points P11, P12 (Ponta de Pedras) and P13 (Barra de Catuama), all located near the animal facility, scored negative for the presence of sandflies. It is important to note that this study provides the first description of L. whitmani, the vector of L. braziliensis, in the municipality of Goiana. Statistically, L. longipalpis was detected more frequently near the animal facility ecotype (P7 and P8) in Atapuz, whereas in Carne de Vaca this species predominated in traps (P1 and P2) that had been installed in the tree ecotype $\left(x^{2}=1,246.88 ; \mathrm{p}=0.0000\right)$.

The kernel map showed a heterogeneous spatial distribution of sandflies on the coast of the municipality of Goiana with a hotspot in the southeast region, more precisely in the Atapuz (Figure 2).

Specimens were obtained throughout the study period, with a monthly mean of 433.33 sandflies (minimum of 4 and maximum of 1,748 specimens). The average number of sandflies and the climatic parameters are shown in Figure 3. The rainfall and relative humidity influenced positively $(\mathrm{p}<0.05)$ the number of specimens collected, whereas no influence was observed regarding temperature $(\mathrm{p}>0.05)$. Reference species were deposited in the entomological collection of the Parasitology Laboratory of the Garanhuns Academic Unit, Federal Rural University of Pernambuco, under protocol number 45/2018.

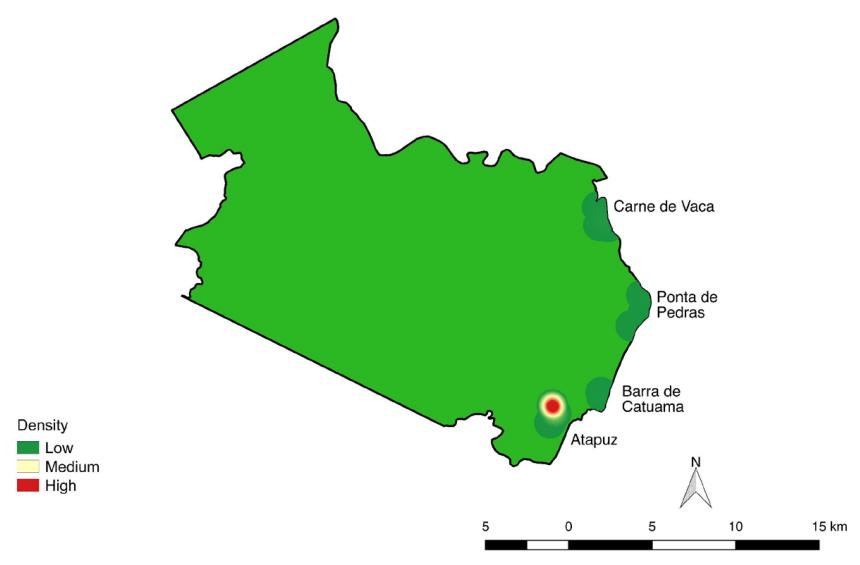

Figure 2. Kernel estimation map showing the density of sandflies in the area of study.

Table 1. Sandflies species collected of Goiana - Pernambuco, from November 2017 to October 2018, using light traps of the Centers for Disease Control (CDC) model.

\begin{tabular}{|c|c|c|c|c|c|c|}
\hline & & L. longipalpis & L. evandroi & L. whitmani & Total & Localities \\
\hline & & & & & & Locanties \\
\hline Carne de Vaca & P1 & $1.75 \pm 0.82^{\mathrm{e}}$ & 0 & 0 & $1.75 \pm 0.82^{\mathrm{e}}$ & $1.85 \pm 0.97^{b}$ \\
\hline & P2 & $5.17 \pm 2.69^{d}$ & 0 & 0 & $5.17 \pm 2.69^{d}$ & \\
\hline & P3 & $0.42 \pm 0.34^{\mathrm{e}}$ & 0 & 0 & $0.42 \pm 0.34^{\mathrm{e}}$ & \\
\hline & P4 & $0.08 \pm 0.08^{\mathrm{e}}$ & 0 & 0 & $0.08 \pm 0.08^{\mathrm{e}}$ & \\
\hline Atapuz & P5 & $0.08 \pm 0.08^{\mathrm{e}}$ & 0 & 0 & $0.08 \pm 0.08^{\mathrm{e}}$ & $106.02 \pm 43.89^{a}$ \\
\hline & P6 & $17.58 \pm 4.37^{\mathrm{c}}$ & 0 & 0 & $17.58 \pm 4.37^{c}$ & \\
\hline & P7 & $50.67 \pm 41.33^{b}$ & 0 & 0 & $50.67 \pm 41.33^{b}$ & \\
\hline & P8 & $355.00 \pm 129.62^{a}$ & $0.16 \pm 0.16^{\mathrm{a}}$ & $0.08 \pm 0.08$ & $355.75 \pm 129.55^{a}$ & \\
\hline Ponta de Pedras & P9 & $0.17 \pm 0.11^{\mathrm{e}}$ & 0 & 0 & $0.17 \pm 0.11^{\mathrm{e}}$ & $0.62 \pm 0.28^{c}$ \\
\hline & P10 & $0.67 \pm 0.43^{\mathrm{e}}$ & $0.41 \pm 0.25^{a}$ & 0 & $1.08 \pm 0.45^{\mathrm{e}}$ & \\
\hline Barra de Catuama & P14 & $0.25 \pm 0.18^{e}$ & 0 & 0 & $0.25 \pm 0.18^{e}$ & $0.33 \pm 0.23^{c}$ \\
\hline & P15 & $0.67 \pm 0.43^{\mathrm{e}}$ & 0 & 0 & $0.67 \pm 0.43^{\mathrm{e}}$ & \\
\hline & P16 & $0.08 \pm 0.08^{\mathrm{e}}$ & 0 & 0 & $0.08 \pm 0.08^{\mathrm{e}}$ & \\
\hline
\end{tabular}

$\bar{x}=$ mean number of sandflies. $\mathrm{SE}=$ standard error. Different letters in the same column indicate statistically significant difference. 


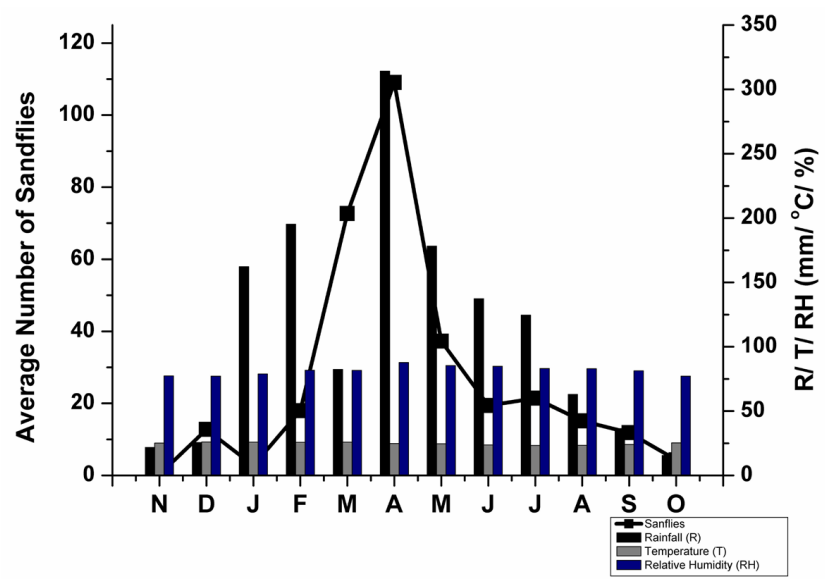

Figure 3. Occurrence of sandflies in Goiana, PE and climatic conditions observed in the study from November 2017 to October 2018.

\section{Discussion}

This study assessed phlebotomine fauna and demonstrated that the vector for $L$. infantum was present throughout the year in an endemic area on the Brazilian coast. Low species diversity was observed. From an epidemiological point of view, this finding is relevant given that vector species both for VL (L. longipalpis; 99.85\%) and for CL (L. whitmani; 0.02\%) were collected. It is important to highlight that the present study provides the first record of L. whitmani in the municipality of Goiana. This municipality is considered to be a priority for the control program for VL, which is a neglected disease (PERNAMBUCO, 2015). Cases of CL have already been reported in this area (SINAN, 2019), thus demonstrating that autochthonous transmission is probably occurring, since the vector, reservoir (PESSOA-E-SILVA et al., 2019) and susceptible host share the same ecological niche. Findings of L. evandroi in the same ecotype as L. longipalpis (P8 and P10) have commonly been observed in previous studies (CHAGAS et al., 2016; FIGUEIREDO et al., 2016).

Interestingly, $97.92 \%(5,089 / 5,197)$ of the specimens were collected in Atapuz $(\bar{x}=106.02 \pm 43.89)$, and specimens of L. longipalpis were collected from there throughout the study period. In this area, the predominant vegetation comprises fragments of Atlantic Forest and mangroves, and chickens are widely present, with predominance of these animals mainly at point P8 where many phlebotomines $(\bar{x}=355.00 \pm 129.62)$ were collected. The environmental conditions observed in this area as presence of vegetation and organic material facilitate proliferation of sandflies (COSTA et al., 2013). In addition, chickens are among the preferred hosts from which $L$. longipalpis obtains its blood meal (BARATA et al., 2005). Other important factors that favor the presence of sandflies in peridomestic areas include proximity of homes to forested areas and low sanitary conditions, with presence of organic matter and natural shelters for these insects (CAMARGO-NEVES et al., 2001). The predominance of phlebotomine in peridomestic areas has been observed worldwide (BOUTSINI et al., 2018).
It is already been demonstrated that climatic conditions are one of the most important factors influencing the density of the sandfly population (SILVA et al., 2018). In the present study, rainfall and relative humidity $(\mathrm{p}<0.05)$ influenced the numbers of sandflies collected. Previous studies have demonstrated an increase in the number of sandflies associated with the increase of rainfall (QUEIROZ et al., 2012), as well as the dispersion of VL (GAO \& CAO, 2019).

The data of the present study are pivotal for attaining better understanding of the dynamics of Leishmania infection in endemic areas. In addition, they serve to alert the healthcare services, since L. longipalpis was detected throughout the year and vectors relating to $\mathrm{CL}$ were reported for the first time. People living in this area are at risk of infection; therefore, preventive vector control measures need to be implemented in order to reduce the risk of transmission.

\section{References}

Agra MCR, Costa PL, Duque AES, Soares ENL, Alves LC, Ramos RAN, et al. Sandflies (Diptera: Psychodidae) in an urban area of Northeastern Brazil. Rev Soc Bras Med Trop 2016; 49(6): 698-702. http:// dx.doi.org/10.1590/0037-8682-0147-2016. PMid:28001216.

Akhoundi M, Kuhls K, Cannet A, Votýpka J, Mary P, Delaunay PMP, et al. A historical overview of the classification, evolution, and dispersion of Leishmania parasites and sandflies. PLoS Negl Trop Dis 2016; 10(6): e0004770. http://dx.doi.org/10.1371/journal.pntd.0004770. PMid:27253524.

Andrade-Filho JD, Scholte RGC, Amaral ALG, Shimabukuro PHF, Carvalho OS, Caldeira RL. Occurrence and Probability Maps of Lutzomyia longipalpis and Lutzomyia cruzi (Diptera: Psychodidae: Phlebotominae) in Brazil. JMed Entomol 2017; 54(5): 1430-1434. http://dx.doi.org/10.1093/ jme/tjx094. PMid:28472338.

Antonini Y, Fernandes GW, Barata RA. Distribution of the assemblage of phlebotomine sandflies (Diptera: Psychodidae) along an environmental gradient. Biota Neotrop 2017; 17(2): e20160253. http://dx.doi. org/10.1590/1676-0611-bn-2016-0253.

Barata RA, França-Silva JC, Mayrink W, Silva JC, Prata A, Lorosa ES, et al. Aspectos da ecologia e do comportamento de flebotomíneos em área endêmica de leishmaniose visceral, Minas Gerais. Rev Soc Bras Med Trop 2005; 38(3): 421-425. http://dx.doi.org/10.1590/S003786822005000500012 . PMid:16172760.

Boutsini S, Athanasiou LV, Spanakos G, Ntousi D, Dotsika E, Bisia $\mathrm{M}$, et al. Phlebotomine sandflies and factors associated with their abundance in the leishmaniasis endemic area of Attiki, Greece. Parasitol Res 2018; 117(1): 107-113. http://dx.doi.org/10.1007/s00436-0175675-8. PMid:29127526.

Brasil. Ministério da Saúde. Secretaria de Vigilância em Saúde. Leishmaniose Visceral: o que é, causas, sintomas, tratamento, diagnóstico e prevenção [online]. Brasília: Ministério da Saúde; 2018 [cited 2019 Apr 19]. Available from: http://portalms.saude.gov.br/saude-de-a-z/leishmaniose-visceral

Brito ME, Andrade MS, Dantas-Torres F, Rodrigues EH, Cavalcanti MP, de Almeida AM, et al. Cutaneous leishmaniasis in northeastern Brazil: a critical appraisal of studies conducted in State of Pernambuco. Rev Soc Bras Med Trop 2012; 45(4): 425-429. http://dx.doi.org/10.1590/ S0037-86822012005000006. PMid:22836662. 
Camargo-Neves VLF, Katz G, Rodas LAC, Poletto DW, Lage LC, Spinola RMF, et al. Utilizaçáo de ferramentas de análise espacial na vigilância epidemiológica de leishmaniose visceral americana - Araçatuba, São Paulo, Brasil, 1998-1999. Cad Saúde Publica 2001; 17(5): 1263-1267. http:// dx.doi.org/10.1590/S0102-311X2001000500026. PMid:11679900.

Chagas AP, Soares DC, Sousa GCR, Viana RB, Rebelo JMM, Garcez LM. Aspectos ecológicos da fauna de flebotomíneos em focos de leishmaniose na Amazônia Oriental, Estado do Pará, Brasil. Rev Pan-Amaz Saude 2016; 7(esp): 123-132. http://dx.doi.org/10.5123/S2176-62232016000500014.

Costa PL, Dantas-Torres F, Silva FJ, Guimarães VCFV, Gaudêncio K, Brandão-Filho SP. Ecology of Lutzomyia longipalpis in an area of visceral leishmaniasis transmission in north-eastern Brazil. Acta Trop 2013; 126(2): 99-102. http://dx.doi.org/10.1016/j.actatropica.2013.01.011. PMid:23369878.

Figueiredo HR, Santos MFC, Casaril AE, Infran JOM, Ribeiro LM, Fernandes CES, et al. Sand flies (Diptera: Psychodidae) in an endemic area of leishmaniasis in Aquidauana municipality, Pantanal of Mato Grosso do Sul, Brazil. Rev Inst Med Trop São Paulo 2016; 58(0): 87. http://dx.doi.org/10.1590/s1678-9946201658087. PMid:27982353.

Gao X, Cao Z. Meteorological conditions, elevation and land cover as predictors for the distribution analysis of visceral leishmaniasis in Sinkiang province, Mainland China. Sci Total Environ 2019; 646: 1111-1116. http://dx.doi.org/10.1016/j.scitotenv.2018.07.391. PMid:30235597.

Goiana. Prefeitura. Secretaria de Planejamento, Meio Ambiente e Patrimônio Histórico. Banco de dados de Goiana [online]. Goiania: Prefeitura Municipal; 2019 [cited 2019 Apr 2]. Available from: https:// www.cidade-brasil.com.br>municipio-goiana

Guimarães VCFV, Costa PL, Silva FJ, Silva KT, Silva KG, Araújo AIF, et al. Phlebotomine sandflies (Diptera: Psychodidae) in São Vicente Férrer, a sympatric area to cutaneous and visceral leishmaniasis in the state of Pernambuco, Brazil. Rev Soc Bras Med Trop 2012; 45(1): 66-70. http:// dx.doi.org/10.1590/S0037-86822012000100013. PMid:22370831.

Lima BS, Dantas-Torres F, Carvalho MR, Marinho-Junior JF, Almeida EL, Brito ME, et al. Small mammals as hosts of Leishmania spp. in a highly endemic area for zoonotic leishmaniasis in north-eastern Brazil. Trans $R$ Soc Trop Med Hyg 2013; 107(9): 592-597. http://dx.doi.org/10.1093/ trstmh/trt062. PMid:23868744.

Lucena DT, Oliveira MHCC, Leal MC. Variação mensal dos flebotomíneos (Diptera - Psychodidae) de Igarassu, PE. Cad Ômega Série Biol 1984; 1(1): 19-27.

Maroli M, Feliciangeli MD, Bichaud L, Charrel RN, Gradoni L. Phlebotomine sandflies and the spreading of leishmaniases and other diseases of public health concern. Med Vet Entomol 2013; 27(2): 123-147. http://dx.doi.org/10.1111/j.1365-2915.2012.01034.x. PMid:22924419.

Miranda DEO, Sales KGS, Faustino MAG, Alves LC, Brandão-Filho SP, Dantas-Torres F, et al. Ecology of sand flies in a low-density residential rural area, with mixed forest/agricultural exploitation, in north-eastern Brazil. Acta Trop 2015; 146: 89-94. http://dx.doi.org/10.1016/j. actatropica.2015.03.011. PMid:25792416.

Pernambuco. Secretaria Estadual de Saúde. Plano Integrado de Açóes para o Enfretamento às Doenças Negligenciadas no Estado de Pernambuco I SANAR 2015-2018 [online]. Recife: Secretaria Estadual de Saúde; 2015 [cited 2015 May 15]. Available from: https://www.portal.saude.pe.gov.br
Pessoa-e-Silva R, Vaitkevicius-Antão V, Andrade TAS, Silva ACO, Oliveira GA, Trajano-Silva LAM, et al. The diagnosis of canine visceral leishmaniasis in Brazil: confronting old problems. Exp Parasitol 2019; 199: 9-16. http://dx.doi.org/10.1016/j.exppara.2019.02.012. PMid:30796913.

Queiroz MFM, Varjāo JR, Moraes SC, Salcedo GE. Analysis of sandflies (Diptera: Psychodidae) in Barra do Garças, State of Mato Grosso, Brazil, and the influence of environmental variables on the vector density of Lutzomyia longipalpis (Lutz \& Neiva, 1912). Rev Soc Bras Med Trop 2012; 45(3): 313-317. http://dx.doi.org/10.1590/S0037-86822012000300007. PMid:22760128.

Ready PD. Biology of phlebotomine sand flies as vectors of disease agents. Annu Rev Entomol 2013; 58(1): 227-250. http://dx.doi.org/10.1146/ annurev-ento-120811-153557. PMid:23317043.

Regis LN, Acioli RV, Silveira JC Jr, Melo-Santos MAV, Souza WV, Ribeiro CMN, et al. Sustained reduction of the dengue vector population resulting from an integrated control strategy applied in two Brazilian Cities. PLoS One 2013; 8(7): 1-12. http://dx.doi.org/10.1371/journal. pone.0067682. PMid:23844059.

Rigg CA, Calzada JE, Saldaña A, Perea M, Chaves LF, Valderrama A. Leishmania spp. infection rate and feeding patterns of sand flies (Diptera: Psychodidae) from a hyperendemic cutaneous leishmaniasis community in Panamá. Am J Trop Med Hyg 2019; 100(4): 798-807. http://dx.doi. org/10.4269/ajtmh.17-0628. PMid:30793681.

Sales KGS, Miranda DEO, Costa PL, Silva FJ, Figueredo LA, BrandãoFilho SP, et al. Home sweet home: sand flies find a refuge in remote indigenous villages in north-eastern Brazil, where leishmaniasis is endemic. Parasit Vectors 2019; 12(1): 118. http://dx.doi.org/10.1186/s13071-0193383-1. PMid:30909958.

Silva APO, Miranda DEO, Santos MAB, Guerra NR, Marques SR, Alves LC, et al. Phlebotomines in an area endemic for American cutaneous leishmaniasis in northeastern coast of Brazil. Rev Bras Parasitol Vet 2017a; 26(3): 280-284. http://dx.doi.org/10.1590/s1984-29612017038. PMid:28902258.

Silva JAO, Carvalho GA, Faustino MAG. Dinâmica da leishmaniose visceral humana no município de Goiana - PE. Pubvet 2017b; 11(12): 1293-1297. http://dx.doi.org/10.22256/pubvet.v11n12.1292-1297.

Silva KB, Silvino ACS, Oliveira JS, Dias RV, Sousa-Paula LC, Braga PET. Flutuação sazonal e frequência horária de flebotomíneos numa área urbana de Sobral, Ceará, Brasil. Rev Saude Biol 2018; 13(1): 12-20.

Sistema Nacional de Agravos de Notificações - SINAN. Portal da saúde: DATASUS [online]. Brasília: Ministério da Saúde; 2019 [cited 2019 Jan 12]. Available from: http://www2.datasus.gov.br/DATASUS/index.php? area $=0203$ \&id $=29878153$

Sousa JMS, Ramalho WM, Melo MA. Demographic and clinical characterization of human visceral leishmaniasis in the State of Pernambuco, Brazil between 2006 and 2015. Rev Soc Bras Med Trop 2018; 51(5): 622630. http://dx.doi.org/10.1590/0037-8682-0047-2018. PMid:30304268.

Young DG, Duncan MA. Guide to the identification and geographic distribution of Lutzomyia sand flies in Mexico, the West Indies, Central and South America (Diptera: Psychodidae). Gainesville: Associated Publishers, American Entomological Institute; 1994. Memoirs of the American Entomological Institute, n. 54. 